\title{
Risk factors of endometrial cancer in patients with endometrial hyperplasia: implication for clinical treatments
}

Jie Zhao', Yongting Hu', Yanan Zhao², Dongmei Chen², Tingfeng Fang² and Miao Ding ${ }^{2^{*}}$

\begin{abstract}
Background: Endometrial hyperplasia $(E H)$ is commonly-seen in the patients with endometrial cancer $(E C)$, we aimed to evaluated the risk factors of $E C$ in patients with $E H$, to provide evidence to the clinical prevention and treatment of EC.

Methods: This study was a retrospective study design. EH patients confirmed by pathological examinations and treated with hysterectomy in our hospital from June 1, 2018 to February 28, 2021 were included. The clinical characteristics of EC and no-EC patients were compared and analyzed. Logistics regression analyses were conducted to evaluate the risk factors of $\mathrm{EC}$ in patients with $\mathrm{EH}$.

Results: A total of $228 \mathrm{EH}$ patients were included, the incidence of $\mathrm{EC}$ in the $\mathrm{EH}$ patients was $31.58 \%$. There were significant differences in the age, BMI, diabetes, hypertension and pathology of EH between EC and no EC groups (all $P<0.05)$, no significant differences in the hyperlipidemia, preoperative $C_{125}$, number of deliveries, menopause and endometrial thickness between EC and no EC groups were found (all $P>0.05$ ). Logistic regression analyses indicated that age $>50$ y (OR 3.064, 95\% Cl 1.945-5.931), BMl $\geq 25 \mathrm{~kg} / \mathrm{m}^{2}$ (OR 2.705, 95\% Cl 1.121-3.889), diabetes (OR 3.049, 95\% Cl 1.781-5.114), hypertension (OR 2.725, 95\% Cl 1.108-3.431) and severe hyperplasia (OR 3.181, 95\% Cl 1.4964.228) were the risk factors of $\mathrm{EC}$ in patients with $\mathrm{EH}$ (all $P<0.05$ ).
\end{abstract}

Conclusions: The risk of EC in EH patients is high, especially for those patients with age $>50 \mathrm{y}, \mathrm{BMI} \geq 25 \mathrm{~kg} / \mathrm{m}^{2}$, diabetes, hypertension and severe hyperplasia, special attentions should be paid for occurrence of EC and early diagnosis and early treatment are needed for those patients.

Keywords: Endometrial cancer, Endometrial hyperplasia, Gynecology, Treatment, Care, Nursing

\section{Background}

Endometrial cancer (EC) is one of the common malignant tumors in gynecology, and its incidence is increasing year by year, and is showing a trend of younger onset age [1]. It is generally believed that the continuous stimulation of estrogen without progesterone antagonism leads

\footnotetext{
*Correspondence: dingmiao@mail.sysu.edu.cn

${ }^{2}$ Department of Obstetrics and Gynecology, Sun Yat-sen Memorial Hospital of Sun Yat-sen University, No. 107 Road Yanjiang West, Guangzhou, China

Full list of author information is available at the end of the article
}

to endometrial hyperplasia and then cancerous transformation $[2,3]$. Endometrial hyperplasia $(\mathrm{EH})$ is a common gynecological endocrine disease, which mainly manifests as irregular vaginal bleeding, infertility, and even malignant transformation [4]. Endometrial dysplasia has certain tendency to become cancerous, and it is recognized as a precancerous lesion of EC with incidence of 23.15$29.08 \%[5,6]$. Therefore, early detection and intervention of $\mathrm{EH}$ is of great significance to improve the prognosis of patients. 
Previous studies $[7,8]$ have shown that it's very common that $\mathrm{EH}$ and $\mathrm{EC}$ can coexist in patients. The risk of endometrial dysplasia combined with endometrial cancer is as high as 25.76 to $59.22 \%$ [9, 10]. Clinically, there is a certain missed diagnosis rate in the diagnosis of $\mathrm{EC}$ [11]. How to identify high-risk patients with EC from patients with $\mathrm{EH}$, is important to guide clinical treatment decisions and improve the prognosis of patients. Therefore, this present study analyzed the clinicopathological data of patients diagnosed with $\mathrm{EH}$ before hysterectomy, aimed to explore the high-risk factors of EC in patients with $\mathrm{EH}$, to provide evidence support to the early prevention and clinical treatment of EC.

\section{Methods}

\section{Ethics}

This study was a retrospective study design. In this study, all methods were conducted in comply with the relevant guidelines and regulations. This present study had been verified and approved by the ethical committee of our hospital (approval number: MD10180068-2c), and written informed consents had been obtained from all the included patients.

\section{Patients}

We selected $\mathrm{EH}$ patients treated with hysterectomy in our hospital from June 1, 2018 to February 28, 2021 as the study populations. The criterial for patient inclusion were: the endometrial thickness was determined by the B-ultrasound (endometrial thickness $\geq 4 \mathrm{~mm}$ ) and pathological examinations, the ultrasound examinations of all selected patients were performed by the same group of sonographers in our hospital; patients underwent hysterectomy treatment in our hospital, and there were complete postoperative pathological reports; there was no history of hormone replacement therapy in the past 1 year. All consecutive patients meeting the selection criteria were included. Patients who did not agree to participant in this study and did not sign the inform consents were excluded.

\section{Data collection}

We collected personal and treatment information of patients, including age, body mass index (BMI), diabetes, hypertension, hyperlipidemia, preoperative CA125 (U/ $\mathrm{ml}$ ) level, number of deliveries, menopause status, preoperative endometrial thickness, and the final pathological results.

\section{Treatment and follow-up}

The diagnosis of EH referred to relevant standards and criteria [12,13], and EH was divided into mild, moderate, and severe group according to the degree of disease.
All patients underwent total hysterectomy in our hospital. According to the final pathological results after total hysterectomy, it was judged whether EC existed at the same time, and the diagnosis of EC referred to relevant standards. If the postoperative pathological examination results suggested that there was EC, further corresponding treatments were conducted. We conducted follow-up till the discharge of patients.

\section{Statistical method}

We used SPSS 24.0 software to analyze the data, and the measurement data were expressed as mean \pm standard deviation, and the comparison between the two groups used independent sample $t$ test. Categorical variables were expressed as percentages, and Chi-square or Fisher exact probability tests were used for comparison between groups. We used logistic multiple regression analysis to explore high-risk factors related to EC. In this study, the difference was statistically significant with $P<0.05$.

\section{Results \\ Patients}

A total of $228 \mathrm{EH}$ patients were included, of whom 72 patients had $\mathrm{EC}$, the incidence of $\mathrm{EC}$ in the $\mathrm{EH}$ patients was $31.58 \%$. As presented in Table 1, there were significant differences in the age, BMI, diabetes, hypertension and pathology of EH between EC and no EC groups (all $P<0.05)$, no significant differences in the hyperlipidemia, preoperative $\mathrm{CA}_{125}$, number of deliveries, menopause and endometrial thickness between EC and no EC groups were found (all $P>0.05$ ).

\section{Risk factors of EC in patients with EH}

The variable assignments of multivariate logistic regression were presented in Table 2. As indicated in Table 3, logistic regression analyses indicated that age $>50$ y (OR $3.064,95 \%$ CI $1.945-5.931$ ), $\mathrm{BMI} \geq 25 \mathrm{~kg} / \mathrm{m}^{2}$ (OR 2.705, 95\% CI 1.121-3.889), diabetes (OR 3.049, 95\% CI 1.7815.114), hypertension (OR 2.725, 95\% CI 1.108-3.431) and severe hyperplasia (OR 3.181, 95\% CI 1.496-4.228) were the risk factors of EC in patients with EH (all $P<0.05)$.

\section{Discussions}

The results of this present study have found that the incidence of EC in the EH patients was $31.58 \%$, which is similar to previous reports $[14,15]$. Besides, we have found that for patients with age $>50 \mathrm{y}, \mathrm{BMI} \geq 25 \mathrm{~kg} / \mathrm{m}^{2}$, diabetes, hypertension and severe hyperplasia, they may have higher risks of EC in patients with $\mathrm{EH}$, early targeted preventions and interventions are needed for patients with those factors. The increase in estrogen levels in the body caused by various reasons continuously stimulates the proliferation of endometrial tissue [16]. The proliferated 
Table 1 The characteristics of included patients

\begin{tabular}{|c|c|c|c|c|}
\hline Variables & EC group $(n=72)$ & No EC group $(n=156)$ & $x^{2} / t$ & $P$ \\
\hline Age (y) & $54.33 \pm 9.26$ & $46.12 \pm 9.39$ & 8.124 & 0.021 \\
\hline BMI $\left(\mathrm{kg} / \mathrm{m}^{2}\right)$ & $27.16 \pm 4.54$ & $23.11 \pm 5.95$ & 6.101 & 0.036 \\
\hline Diabetes & $39(54.17 \%)$ & $44(28.21 \%)$ & 1.114 & 0.019 \\
\hline Hypertension & $52(72.22 \%)$ & $68(43.59 \%)$ & 1.271 & 0.038 \\
\hline Hyperlipidemia & $17(23.61 \%)$ & $30(19.23 \%)$ & 1.855 & 0.076 \\
\hline Preoperative $\mathrm{CA}_{125}(\mathrm{U} / \mathrm{ml})$ & $21.69 \pm 5.14$ & $19.88 \pm 4.24$ & 1.232 & 0.095 \\
\hline \multicolumn{5}{|l|}{ Number of deliveries } \\
\hline 0 & $8(11.11 \%)$ & $20(12.82 \%)$ & 1.140 & 0.011 \\
\hline 1 & $22(30.56 \%)$ & $48(30.77 \%)$ & & \\
\hline 2 & $37(51.39 \%)$ & $77(49.36 \%)$ & & \\
\hline$\geq 3$ & $5(6.94 \%)$ & $11(49.36 \%)$ & & \\
\hline Menopause & $31(43.06 \%)$ & $63(40.38 \%)$ & 3.114 & 0.065 \\
\hline \multicolumn{5}{|l|}{ Pathology of EH } \\
\hline Mild hyperplasia & $8(11.11 \%)$ & $59(37.82 \%)$ & 1.892 & 0.008 \\
\hline Moderate hyperplasia & $20(27.78 \%)$ & $85(54.49 \%)$ & & \\
\hline Severe hyperplasia & $44(61.11 \%)$ & $12(7.69 \%)$ & & \\
\hline Endometrial thickness (mm) & $10.27 \pm 3.21$ & $9.98 \pm 2.02$ & 1.774 & 0.102 \\
\hline
\end{tabular}

EC endometrial cancer, $E H$ endometrial hyperplasia

Table 2 The variable assignment of multivariate logistic regression

\begin{tabular}{lll}
\hline Factors & Variables & Assignment \\
\hline EC & $Y$ & Yes $=1, \mathrm{no}=2$ \\
Age $(\mathrm{y})$ & $X_{1}$ & $\geq 50=1,<50=2$ \\
BMl $\left(\mathrm{kg} / \mathrm{m}^{2}\right)$ & $X_{2}$ & $\geq 25=1,<25=2$ \\
Diabetes & $X_{3}$ & Yes $=1, \mathrm{No}=2$ \\
Hypertension & $X_{4}$ & Yes $=1, \mathrm{No}=2$ \\
Pathology of EH & $X_{5}$ & Severe hyperplasia = 1, moderate \\
& & hyperplasia = 2, mild hyperpla- \\
& & sia $=3$
\end{tabular}

$E C$ endometrial cancer, $B M I$ body mass index, $E H$ endometrial hyperplasia

Table 3 The logistic regression analysis on the risk factors of endometrial cancer in patients with endometrial hyperplasia

\begin{tabular}{llllll}
\hline Variables & $\boldsymbol{\beta}$ & $\mathbf{S} \overline{\mathrm{x}}$ & $\mathbf{O R}$ & $\mathbf{9 5 \%} \mathbf{C l}$ & $\boldsymbol{P}$ \\
\hline Age $>50 \mathrm{y}$ & 0.121 & 0.287 & 3.064 & $1.945-5.931$ & 0.012 \\
$\mathrm{BMI} \geq 25 \mathrm{~kg} / \mathrm{m}^{2}$ & 0.115 & 0.206 & 2.705 & $1.121-3.889$ & 0.027 \\
Diabetes & 0.106 & 0.152 & 3.049 & $1.781-5.114$ & 0.009 \\
Hypertension & 0.142 & 0.187 & 2.725 & $1.108-3.431$ & 0.034 \\
Severe hyperplasia & 0.119 & 0.105 & 3.181 & $1.496-4.228$ & 0.019 \\
\hline
\end{tabular}

$B M I$ body mass index, $O R$ odds ratio, $\mathrm{Cl}$ confidence interval

endometrial tissue is stimulated by a single estrogen for a long time without progesterone antagonism, which is likely to cause excessive endometrial cell proliferation [17]. Tumor cells infiltrate local blood vessels or necrosis and disintegration of their own tissues can cause bleeding [18]. The most common pathological type of endometrial cancer is endometrioid adenocarcinoma, which accounts for about 74.25 to $80.11 \%[19,20]$. Therefore, the early identification and treatment of $\mathrm{EC}$ in the $\mathrm{EH}$ patients is vital to the prognosis of $\mathrm{EH}$ patients.

The main cause is the long-term estrogen exposure of the endometrium and the lack of progesterone antagonism [21]. It is generally believed that endometrial cancer is more likely to occur in perimenopausal women [22]. Studies [23-25] have pointed out that age is a high-risk factor for endometrial dysplasia coexisting with EC. Previous study [26] has reported that endometrial hyperplasia patients aged 40-59 have an increased risk of endometrial cancer (OR 3.07, 95\% CI 1.18-7.97); The risk is higher when the age is $\geq 60$ (DR 6.65, 95\% CI 1.75-25.3). The potential reasons may be that due to the perimenopausal age at which EC is likely to occur, which is related to the decline of the body's immune function [27]. It's been reported that the incidence of EC under the age of 50 is 102 per 100,000, while the incidence of EC over the age of 50 has risen to 1374 per 100,000 [28]. The older the age, the more severe the disease and the lower the survival rate [29]. The results of this study also suggest that age $\geq 50$ years old is a high-risk factor for the development of EC. Therefore, for the elderly, especially those with $\mathrm{EH}$ aged $\geq 48$ years, they need to be treated with caution in clinical practice.

The pathological change of $\mathrm{EH}$ must be considered in the diseases progress. Among endometrial diseases, $\mathrm{EH}$ 
is the most common benign disease, and $\mathrm{EC}$ is one of the most common female reproductive system tumors, accounting for 20 to $30 \%$ of female reproductive tract malignant tumors [30]. In the past 20 years, the incidence of endometrial cancer has shown an obvious upward trend [31]. It is generally believed that endometrial lesions are a process in which the lesions continue to progress, that is, from not accompanied by $\mathrm{EH}$ to accompanied by $\mathrm{EH}$, and finally progressing to well-differentiated EC [32, 33]. However, some scholars [21, 34] have reported that the incidence of EC in patients with endometrial hyperplasia is $12.18-46.34 \%$. The results of this study also suggest that severe $\mathrm{EH}$ is also a high-risk factor for EC. However, the clinical reason for the failure to find coexisting EC before surgery may be that the preoperative endometrial sampling is mainly by diagnosing curettage, AEH lesions may be single or scattered lesions, which are affected by the experience of the surgeon, and there is a possibility of missed curettage $[35,36]$. In addition, the diagnosis of well-differentiated EC is mainly based on the presence or absence of endometrial stroma, but it is sometimes difficult to determine [37]. This study has found that the risk of patients with endometrial cancer increase significantly with the severity of EH. Therefore, for patients whose endometrial biopsy pathology is severe $\mathrm{EH}$, due to the high probability of EC, early alerts of EC are needed for those patients.

Several high-risk factors for EC should be concerned and get the attentions of clinical health workers. Studies $[38,39]$ have pointed out that obesity and diabetes are high-risk factors for EC. For every $5 \mathrm{~kg} / \mathrm{m}^{2}$ increase in BMI, the risk of EC increases 1.6 times. Several studies $[40,41]$ have also shown that obesity in patients with endometrial cancer also increases the risk of endometrial cancer-related deaths. The reason is that adipose tissue is the source of estrogen in the body. Obesity causes excessive endogenous estrogen to act on the endometrium, leading to EH and EC. Studies [3, 42, 43] have shown that when the insulin resistance index is greater than or equal to 2.8809 , the relative risks of endometrial hyperplasia and endometrial cancer are 35.22 and 30.59 , respectively. It's been found that when BMI $\geq 25 \mathrm{~kg} / \mathrm{m}^{2}$, progesterone treatment is less effective and prone to recurrence. Therefore, weight control should be strengthened during treatment and follow-up. Simple hypertension does not increase the occurrence of endometrial cancer, but hypertension patients are often complicated by obesity and diabetes. Therefore, early control of weight, blood sugar and blood pressure are vital to improve the prognosis of patients.

It must be noted that the pathological types of EC with coexisting $\mathrm{EH}$ are hormone-dependent $\mathrm{EC}$, more than $90 \%$ are well-differentiated cancers, about $40 \%$ of the lesions are confined to the endometrium, and about $50 \%$ are accompanied by superficial muscle layer infiltration, about $10 \%$ is accompanied by deep muscle layer infiltration [44]. Besides, there may be some immunohistochemical factors in predicting EC in EH patients. AT-rich interaction domain 1A (ARID1A) loss in premalignant $\mathrm{EH}$ is an accurate and almost perfectly specific prognostic marker for coexistent cancer [45]. Besides, it's been found that PTEN loss in EH is a risk factor for EC, but is not reliable in predicting the risk of EC [46]. In this present study, four cases underwent lymph node resection after surgery, and the pathological examination results were negative. There was no recurrence or death due to cancer in the follow-up. Previous study [47] have found that after resection of the uterus due to $\mathrm{EH}$ are highly differentiated stage I cases, with only 6 cases of moderately differentiated cancer and 2 cases of poorly differentiated cancer.

\section{Conclusions}

In conclusion, we have found that the incidence of EC in the $\mathrm{EH}$ patients was $31.58 \%$, age $>50 \mathrm{y}, \mathrm{BMI} \geq 25 \mathrm{~kg} / \mathrm{m}^{2}$, diabetes, hypertension and severe hyperplasia are the independent risk factors of EC in patients with $\mathrm{EH}$. For controllable high-risk factors, such as obesity, diabetes and hypertension, clinical education and intervention should be strengthened with more focus on changes in patients' lifestyles, and early preventions are needed to reduce the development of EC.

\section{Abbreviations}

EC: Endometrial cancer; EH: Endometrial hyperplasia; BMI: Body mass index; OR: Odds ratio; Cl: Confidence interval.

\section{Acknowledgements}

None.

\section{Authors' contributions}

JZ, MD designed research; JZ, YH, YZ, DC, TF, MD conducted research; JZ, YH analyzed data; JZ, MD wrote the first draft of manuscript; MD had primary responsibility for final content. All authors read and approved the final manuscript.

Funding

None.

Availability of data and materials

All data generated or analyzed during this study are included in this published article.

\section{Declarations}

\section{Ethics approval and consent to participate}

In this study, all methods were conducted in comply with the relevant guidelines and regulations. This present study had been verified and approved by the ethical committee of Sun Yat-sen Memorial Hospital of Sun Yat-sen University (approval number: MD10180068-2C), and written informed consents had been obtained from all the included patients. 


\section{Consent for publication \\ Not applicable.}

\section{Competing interests}

The authors declare that they have no competing interests.

\section{Author details}

'Department of Obstetrics and Gynecology, Fuping County Hospital, Weinan, China. ${ }^{2}$ Department of Obstetrics and Gynecology, Sun Yat-sen Memorial Hospital of Sun Yat-sen University, No. 107 Road Yanjiang West, Guangzhou, China.

Received: 5 May 2021 Accepted: 2 August 2021

Published online: 25 August 2021

\section{References}

1. Vetter MH, Smith B, Benedict J, Hade EM, Bixel K, Copeland LJ, Cohn DE, Fowler JM, O'Malley D, Salani R, et al. Preoperative predictors of endometrial cancer at time of hysterectomy for endometrial intraepithelial neoplasia or complex atypical hyperplasia. Am J Obstet Gynecol. 2020;222(1):60.e61-60.e67.

2. Doherty MT, Sanni OB, Coleman HG, Cardwell CR, McCluggage WG, Quinn D, Wylie J, McMenamin UC. Concurrent and future risk of endometrial cancer in women with endometrial hyperplasia: a systematic review and meta-analysis. PLoS ONE. 2020;15(4):e0232231.

3. Jordan SJ, Na R, Weiderpass E, Adami HO, Anderson KE, van den Brandt PA, Brinton LA, Chen C, Cook LS, Doherty JA, et al. Pregnancy outcomes and risk of endometrial cancer: a pooled analysis of individual participant data in the Epidemiology of Endometrial Cancer Consortium. Int J Cancer. 2021;148(9):2068-78.

4. Clarke MA, Long BJ, Sherman ME, Lemens MA, Podratz KC, Hopkins MR, Ahlberg LJ, Mc Guire L, Laughlin-Tommaso SK, Bakkum-Gamez JN, et al. Risk assessment of endometrial cancer and endometrial intraepithelial neoplasia in women with abnormal bleeding and implications for clinical management algorithms. Am J Obstet Gynecol. 2020;223(4):549. e541-549.e513.

5. Padilla-Iserte P, Lago V, Tauste C, Diaz-Feijoo B, Gil-Moreno A, Oliver R, Coronado P, Martin-Salamanca MB, Pantoja-Garrido M, Marcos-Sanmartin J, et al. Impact of uterine manipulator on oncological outcome in endometrial cancer surgery. Am J Obstet Gynecol. 2021;224(1):65.e61-65.e11.

6. Kim S, Park J, Chen Y, Rowe K, Snyder J, Fraser A, Smith K, Deshmukh VG, Newman M, Herget K, et al. Long-term diabetes risk among endometrial cancer survivors in a population-based cohort study. Gynecol Oncol. 2020;156(1):185-93.

7. Saleh M, Virarkar M, Bhosale P, El Sherif S, Javadi S, Faria SC. Endometrial cancer, the Current International Federation of Gynecology and Obstetrics Staging System, and the Role of Imaging. J Comput Assist Tomogr. 2020;44(5):714-29.

8. Jeon J, Kim SE, Lee DY, Choi D. Factors associated with endometrial pathology during tamoxifen therapy in women with breast cancer: a retrospective analysis of 821 biopsies. Breast Cancer Res Treat. 2020;179(1):125-30

9. Yang BY, Gulinazi Y, Du Y, Ning CC, Cheng YL, Shan WW, Luo XZ, Zhang HW, Zhu Q, Ma FH, et al. Metformin plus megestrol acetate compared with megestrol acetate alone as fertility-sparing treatment in patients with atypical endometrial hyperplasia and well-differentiated endometrial cancer: a randomised controlled trial. BJOG. 2020;127(7):848-57.

10. Kokts-Porietis RL, McNeil J, Nelson G, Courneya KS, Cook LS, Friedenreich CM. Prospective cohort study of metabolic syndrome and endometrial cancer survival. Gynecol Oncol. 2020;158(3):727-33.

11. Reinholdt K, Kjaer SK, Guleria S, Frederiksen K, Mellemkjaer L, Munk $C$, Jensen A. Risk of endometrial cancer among women with benign ovarian tumors - a Danish nationwide cohort study. Gynecol Oncol. 2020;157(2):549-54

12. Juan $L$, Jinghe $L$, Lina $G$, Qiaozhi L. Gynecological oncology. Beijing: People's Medical Publishing House; 2016.

13. Association FRDGoPBoCM. Pathological diagnosis criteria for endometrial cancer. Chin J Pathol. 2020;49(3):214-9.
14. Shen L, Wu Y, Li A, Li L, Shen L, Jiang Q, Li Q, Wu Z, Yu L, Zhang X. LncRNA TTNAS1 promotes endometrial cancer by sponging miR376a3p. Oncol Rep. 2020:44(4):1343-54.

15. Giannella L, Delli Carpini G, Sopracordevole F, Papiccio M, Serri M, Giorda G, Tsiroglou D, Del Fabro A, Ciavattini A. Atypical endometrial hyperplasia and unexpected cancers at final histology: a study on endometrial sampling methods and risk factors. Diagnostics (Basel). 2020;10(7):474.

16. Matsuo K, Ramzan AA, Gualtieri MR, Mhawech-Fauceglia P, Machida $H$, Moeini A, Dancz CE, Ueda Y, Roman LD. Prediction of concurrent endometrial carcinoma in women with endometrial hyperplasia. Gynecol Oncol. 2015;139(2):261-7.

17. Rakha E, Wong SC, Soomro I, Chaudry Z, Sharma A, Deen S, Chan S, Abu J, Nunns D, Williamson K, et al. Clinical outcome of atypical endometrial hyperplasia diagnosed on an endometrial biopsy: institutional experience and review of literature. Am J Surg Pathol. 2012;36(11):1683-90.

18. Setiawan VW, Yang HP, Pike MC, McCann SE, Yu H, Xiang YB, Wolk A, Wentzensen N, Weiss NS, Webb PM, et al. Type I and II endometrial cancers: have they different risk factors? J Clin Oncol. 2013;31(20):2607-18.

19. Matsuo K, Mandelbaum RS, Ciccone M, Khoshchehreh M, Pursuwani H, Morocco EB, Matsuzaki S, Dancz CE, Ozel B, Paulson RJ, et al. Routespecific association of progestin therapy and concurrent metformin use in obese women with complex atypical hyperplasia. Int J Gynecol Cancer. 2020;30(9):1331-9.

20. Hutt S, Tailor A, Ellis P, Michael A, Butler-Manuel S, Chatterjee J. The role of biomarkers in endometrial cancer and hyperplasia: a literature review. Acta Oncol. 2019;58(3):342-52.

21. Sanderson PA, Critchley HO, Williams AR, Arends MJ, Saunders PT. New concepts for an old problem: the diagnosis of endometrial hyperplasia. Hum Reprod Update. 2017;23(2):232-54

22. Travaglino A, Raffone A, Saccone G, Mollo A, De Placido G, Insabato L, Zullo F. Endometrial hyperplasia and the risk of coexistent cancer: WHO versus EIN criteria. Histopathology. 2019;74(5):676-87.

23. Pal N, Broaddus RR, Urbauer DL, Balakrishnan N, Milbourne A, Schmeler KM, Meyer LA, Soliman PT, Lu KH, Ramirez PT, et al. Treatment of low-risk endometrial cancer and complex atypical hyperplasia with the levonorgestrel-releasing intrauterine device. Obstet Gynecol. 2018;131(1):109-16.

24. Alcazar JL, Bonilla L, Marucco J, Padilla Al, Chacon E, Manzour N, Salas A. Risk of endometrial cancer and endometrial hyperplasia with atypia in asymptomatic postmenopausal women with endometrial thickness $\geq 11 \mathrm{~mm}$ : a systematic review and meta-analysis. J Clin Ultrasound. 2018;46(9):565-70.

25. Rosen MW, Tasset J, Kobernik EK, Smith YR, Johnston C, Quint EH. Risk factors for endometrial cancer or hyperplasia in adolescents and women 25 years old or younger. J Pediatr Adolesc Gynecol. 2019;32(5):546-9.

26. Trimble CL, Kauderer J, Zaino R, Silverberg S, Lim PC, Burke JJ 2nd, Alberts D, Curtin J. Concurrent endometrial carcinoma in women with a biopsy diagnosis of atypical endometrial hyperplasia: a Gynecologic Oncology Group study. Cancer. 2006;106(4):812-9.

27. Mutter GL, Kauderer J, Baak JP, Alberts D, Gynecologic Oncology G. Biopsy histomorphometry predicts uterine myoinvasion by endometrial carcinoma: a Gynecologic Oncology Group study. Hum Pathol. 2008;39(6):866-74.

28. Ying Z, Fengzhi F, Ying J. High-risk factors and prognosis analysis of endometrial hyperplasia complicated with endometrial cancer. J Pract Obstet Gynecol. 2016:32(11):826-9.

29. Travaglino A, Raffone A, Saccone G, Insabato L, Mollo A, De Placido G, Zullo F. Immunohistochemical predictive markers of response to conservative treatment of endometrial hyperplasia and early endometrial cancer: a systematic review. Acta Obstet Gynecol Scand. 2019;98(9):1086-99.

30. Harrison RF, He W, Fu S, Zhao H, Sun CC, Suidan RS, Woodard TL, RauhHain JA, Westin SN, Giordano SH, et al. National patterns of care and fertility outcomes for reproductive-aged women with endometrial cancer or atypical hyperplasia. Am J Obstet Gynecol. 2019;221(5):474.e471-474 e411.

31. Pennant ME, Mehta R, Moody P, Hackett G, Prentice A, Sharp SJ, Lakshman R. Premenopausal abnormal uterine bleeding and risk of endometrial cancer. BJOG. 2017;124(3):404-11.

32. Yang B, Xu Y, Zhu Q, Xie L, Shan W, Ning C, Xie B, Shi Y, Luo X, Zhang H, et al. Treatment efficiency of comprehensive hysteroscopic evaluation and lesion resection combined with progestin therapy in young women 
with endometrial atypical hyperplasia and endometrial cancer. Gynecol Oncol. 2019;153(1):55-62.

33. Ceylan Y, Akpinar G, Doger E, Kasap M, Guzel N, Karaosmanoglu K, Kopuk SY, Yucesoy I. Proteomic analysis in endometrial cancer and endometrial hyperplasia tissues by 2D-DIGE technique. J Gynecol Obstet Hum Reprod. 2020;49(2):101652.

34. Travaglino A, Raffone A, Saccone G, Mollo A, De Placido G, Mascolo M, Insabato L, Zullo F. Complexity of glandular architecture should be reconsidered in the classification and management of endometrial hyperplasia. APMIS. 2019;127(6):427-34.

35. Hahn HS, Chun YK, Kwon YI, Kim TJ, Lee KH, Shim JU, Mok JE, Lim $\mathrm{KT}$. Concurrent endometrial carcinoma following hysterectomy for atypical endometrial hyperplasia. Eur J Obstet Gynecol Reprod Biol. 2010;150(1):80-3.

36. Man GCW, Wang J, Song Y, Wong JH, Zhao Y, Lau TS, Leung KT, Chan $\mathrm{TH}$, Wang $\mathrm{H}$, Kwong J, et al. Therapeutic potential of a novel prodrug of green tea extract in induction of apoptosis via ERK/JNK and Akt signaling pathway in human endometrial cancer. BMC Cancer. 2020;20(1):964.

37. Zhang G, Chen H, Liu Y, Niu L, Jin L, Li D, Song L, Shang L, Lin X, Wang F, et al. Is lymph node dissection mandatory among early stage endometrial cancer patients? A retrospective study. BMC Womens Health. 2020;20(1):258.

38. Raffone A, Travaglino A, Saccone G, D'Alessandro P, Arduino B, Mascolo M, De Placido G, Insabato L, Zullo F. Diabetes mellitus is associated with occult cancer in endometrial hyperplasia. Pathol Oncol Res. 2020;26(3):1377-84.

39. Travaglino A, Raffone A, Saccone G, D'Alessandro P, Arduino B, de Placido G, Mascolo M, Insabato L, Zullo F. Significant risk of occult cancer in complex non-atypical endometrial hyperplasia. Arch Gynecol Obstet. 2019;300(5):1147-54.

40. Raffone A, Travaglino A, Saccone G, Di Maio A, Mollo A, Mascolo M, De Rosa R, De Placido G, Insabato L, Zullo F. Diabetes mellitus and responsiveness of endometrial hyperplasia and early endometrial cancer to conservative treatment. Gynecol Endocrinol. 2019;35(11):932-7.

41. Garzon S, Uccella S, Zorzato PC, Bosco M, Franchi MP, Student V, Mariani A. Fertility-sparing management for endometrial cancer: review of the literature. Minerva Med. 2021;112(1):55-69.

42. Dashti SG, English DR, Simpson JA, Karahalios A, Moreno-Betancur M, Biessy C, Rinaldi S, Ferrari P, Tjonneland A, Halkjaer J, et al. Adiposity and endometrial cancer risk in postmenopausal women: a sequential causal mediation analysis. Cancer Epidemiol Biomark Prev. 2021:30(1):104-13.

43. Hamilton CA, Pothuri B, Arend RC, Backes FJ, Gehrig PA, Soliman PT, Thompson JS, Urban RR, Burke WM. Endometrial cancer: a society of gynecologic oncology evidence-based review and recommendations, part II. Gynecol Oncol. 2021;160(3):827-34.

44. Cordeiro Mitchell CN, Hunkler KF, Maher JY, Garbose RA, Gornet ME, Whiting-Collins $L$, Christianson MS. Conservatively treated endometrial intraepithelial neoplasia/cancer: risk of intrauterine synechiae. J Gynecol Obstet Hum Reprod. 2021;50(5):101930.

45. Raffone A, Travaglino A, Saccone G, Cieri M, Mascolo M, Mollo A, Insabato L, Zullo F. Diagnostic and prognostic value of ARID1A in endometrial hyperplasia: a novel marker of occult cancer. APMIS. 2019;127(9):597-606.

46. Raffone A, Travaglino A, Saccone G, Viggiani M, Giampaolino P, Insabato L, Mollo A, De Placido G, Zullo F. PTEN expression in endometrial hyperplasia and risk of cancer: a systematic review and meta-analysis. Arch Gynecol Obstet. 2019;299(6):1511-24.

47. Guleria S, Jensen A, Albieri V, Nohr B, Frederiksen K, Kjaer SK. Endometrial cancer risk after fertility treatment: a population-based cohort study. Cancer Causes Control. 2021;32(2):181-8.

\section{Publisher's Note}

Springer Nature remains neutral with regard to jurisdictional claims in published maps and institutional affiliations.
Ready to submit your research? Choose BMC and benefit from:

- fast, convenient online submission

- thorough peer review by experienced researchers in your field

- rapid publication on acceptance

- support for research data, including large and complex data types

- gold Open Access which fosters wider collaboration and increased citations

- maximum visibility for your research: over $100 \mathrm{M}$ website views per year

At BMC, research is always in progress.

Learn more biomedcentral.com/submissions 